\title{
A CHEMICAL AND HISTOCHEMICAL STUDY OF ALKALINE PHOSPHATASE AND ALIESTERASE IN THE EPIDIDYMIS OF NORMAL AND CASTRATE MICE ${ }^{1}$
}

JOHN M. ALLEN AND JUDITH J. SLATER

Department of Zoology, University of Michigan, Ann Arbor, Michigan

SIXTEEN FIGURES

Spermatozoa occupy several days in their passage through the epididymal canal (Mason and Shaver, '52). During this time the spermatozoa acquire increased fertilizing power (Young, '31). These facts suggest that the epididymal cells and their secretory products may play a dual role. First, they may actively participate in the differentiation of the sperm cells; secondly, they must contribute to the well-being of the spermatozoa by making available nutrients or otherwise maintaining a compatible environment.

Few attempts have been made to study the enzymatic characteristics of these epididymal cells by modern histochemical methods. Wislocki ('49) has investigated alkaline phosphatase in the epididymis of the Virginia deer, Maneely ('55) has described the distribution of alkaline phosphatase and certain polysaccharides in the epididymis of the rat, and Iwahashi ('52) has studied the localization of acid phosphatase and alkaline phosphatase in the epididymis of the lizard. No other studies of a complete nature have been carried out histochemically on this tissue although several incidental observations appear in the literature (e.g., Chessick, '53; Fishman and Baker, '56; Montagna, '52; Nicander, '54).

\footnotetext{
1 This research was supporterl by an American Cancer Soeiety Institutional Grant to the University of Michigan.
} 
This paper deals with the chemical and histochemical behavior of alkaline phosphatase and non-specific esterase (aliesterase) in the epididymis of intact and castrate mice.

\section{MATERIALS AND METHODS}

All work was done on epididymides from pure bred BALB/c Jax male mice 90-180 days of age. Tissues for histochemical study were fixed at $4^{\circ} \mathrm{C}$. for 12 hours in $10 \%$ formalin buffered and made isotonic with a phosphate buffer system. Tissues were sectioned on a freezing microtome at 15-20 $\mu$ and drymounted on slides.

Aliesterase was localized according to the modification of Pearse ('53) using alpha-naphthyl acetate (Eastman Kodak Company) as substrate and Fast Blue Salt B (General Dyestuff Company) as dye coupler. Eserine sulfate, $10^{-5} \mathrm{M}$, was added to the substrate solution to block the activity of cholinesterases. Sections were incubated in the substrate solution for 5 minutes at $20^{\circ} \mathrm{C}$. (head pieces) and for 2 or 5 minutes at $20^{\circ} \mathrm{C}$. (tail pieces) with constant agitation.

Alkaline phosphatase was localized according to the modification of Pearse ('53) using sodium alpha-naphthyl acid phosphate (Dajac) as substrate and the stable diazotate of 5chloro-o-toluidine (General Dyestuff Company) as coupling agent. Sections were incubated in the substrate solution for 10 minutes at $20^{\circ} \mathrm{C}$. with constant agitation.

Prior to immersion in the histochemical substrates, all sections were de-fatted for one minute at $20^{\circ} \mathrm{C}$. in acetone. Sections treated with water at $90^{\circ} \mathrm{C}$. for 10 minutes served as controls.

Tissues for quantitative study were homogenized in ice cold $0.9 \% \mathrm{NaCl}$, frozen and thawed 6 times and centrifuged for 15 minutes at $1500 \mathrm{G}$. Each animal furnished the following tissues: (a) one whole epididymis, (b) one proximal portion composed of the head and the anterior half of the body, (c) one distal portion composed of the tail and the posterior half of the body. 
Quantitative determinations of aliesterase activity were made following the procedure of Gomori ('53) and employing alpha-naphthyl acetate (Eastman Kodak Company) as substrate and Fast Red Salt ITR (General Dyestuff Company) as coupling agent. The substrate solution contained $10^{-5} \mathrm{M}$ eserine sulfate. Color developed was read in a Klett-Summerson colorimeter using a $500-570 \mathrm{~m} \mu$ filter.

Quantitative estimation of alkaline phosphatase activity was achieved using a modification of Gomori's method for aliesterase (Gomori, '53) and employing sodium alpha-naphthyl acid phosphate as substrate and Fast Red Salt ITR (Dajac) as coupling agent. The modifications are as follows: (a) Standard solution, $40 \mathrm{ml} 0.1 \mathrm{M}$ vernol buffer $\mathrm{pH} 9.2$ (Pearse, '53) $1 \mathrm{ml} 0.0025 \mathrm{M}$ alpha-naphthol (Eastman Kodak Company), dilute volumetrically to $100 \mathrm{ml}$; (b) Substrate solution, $40 \mathrm{ml}$ $0.1 \mathrm{M}$ veronal buffer $\mathrm{pH} 9.2$ (Pearse, '53), $8 \mathrm{mgm}$ sodium alphanaphthyl acid phosphate (Dajac), dilute volumetrically to 100 ml. Prior to the addition of dye coupler the $\mathrm{pH}$ of each tube was adjusted to neutrality by the addition of a known volume of $0.05 \mathrm{M} \mathrm{HCl}$. Color developed was read in a Klett-Summerson colorimeter using a $500-570 \mathrm{~m} \mu$ filter. The dye formed following addition of Fast Red Salt ITR at $\mathrm{pH} 9.2$ is not stable, therefore $0.05 \mathrm{M} \mathrm{HCl}$ was added to adjust the $\mathrm{pH}$ to near neutrality. In this $\mathrm{pH}$ range the dye produced is stable for at least 30 minutes. In the $\mathrm{pH}$ range $5-8$, light absorption was found to be independent of hydrogen ion concentration.

Total nitrogen in the samples used for quantitative analysis was estimated by a micro-Kjeldahl method (Hawk, '51).

Quantitative data were analyzed statistically by the T-test and Wilcoxon sum methods.

\section{RESULTS}

The microscopic anatomy of the mouse epididymis has been described in detail by Benoit ('26). In Lobe 3 of the head segment of the epididymal canal, a cell type has been observed which was not described by Benoit ('26). These cells are club-shaped, non-ciliated and attach to the basement 
membrane by a thin strand of cytoplasm. The nucleus is situated in the mid-region of the cell in contrast to its basal location in ciliated cells.

\section{Alkaline phosphatase in the normal and castrate animal}

In all regions of the epididymis basal cells show no alkaline phosphatase activity. Nuclei of all cells are negative. Stromal connective tissues and capillaries show moderate levels of enzymatic dye deposition. Heat inactivated sections show no dye formation.

Alkaline phosphatase in histochemically detectable amounts is absent from epithelial cells in Lobe 1 and the proximal portions of Lobe 2 (fig. 1). Low levels of activity are noted in the epithelial cells of the distal portions of Lobe 2. Enzymatic dye deposition in Lobe 3 of the head is increased over that noted in the terminal portion of Lobe 2 (fig. 2). The non-ciliated cells of Lobe 3 are negative for alkaline phosphatase (fig. 9). Maximum alkaline phosphatase activity is noted in Lobes 4 and 5 (fig. 3). The remaining lobes of the head show a similar distribution of alkaline phosphatase activity but the amount of dye deposition progressively decreases to nihil in Lobe 7 (fig. 4). The enzyme, when present, is concentrated in the cilia and apices of the epithelial cells.

Histochemically detectable alkaline phosphatase activity is absent from epithelial cells of the body and tail (fig. 5) segments of the epididymal canal. The lamina propria in the tail shows high levels of alkaline phosphatase activity (fig. 5). Longitudinal fibers of the muscularis in the terminal segment of the tail show moderate levels of activity but the circular fibers appear negative (fig. 5).

Castration for a period of 30 or 60 days abolishes histochemically detectable alkaline phosphatase activity in all epithelial cells and stromal connective tissues (fig. 6). Enzyme activity is reduced in the lamina propria and longitudinal muscle fibers of the tail. Dye deposition in capillaries is unaffected (fig. 6). 
Subcutaneous administration of $10 \mu \mathrm{gm}$ testosterone propionate (Schering) in $0.1 \mathrm{ml}$ sesame oil daily for a period of 14 days to animals castrate for 30 days restores the pattern of alkaline phosphatase activity to that seen in normal control animals.

Quantitative estimates of alkaline phosphatase activity support the histochemical observations. Comparison of specific activity data (table 1 ) shows significantly greater alkaline phosphatase activity in the proximal portion of the

TABLE 1

Specific activity ${ }^{1}$ of alkaline phosphatase in mouse epididymis

\begin{tabular}{|c|c|c|c|c|}
\hline & INTACT & $\begin{array}{l}\text { CASTRATI } \\
\text { 30 DAYS }\end{array}$ & $\begin{array}{l}\text { CABTRATR } \\
\text { 60 DAYS }\end{array}$ & $\begin{array}{c}\text { OABTRATE } \\
\text { 30 DAYS FLUS } \\
10 \mu \text { ML } \\
\text { TESTOETERONE } \\
\text { PROPIONATE } \\
\text { 14 DAYS }\end{array}$ \\
\hline Whole epididymis & $\begin{array}{c}0.927 \pm 0.057 \\
(10)\end{array}$ & $\begin{array}{c}0.332 \pm 0.138 \\
(19)\end{array}$ & $\begin{array}{c}0.159 \pm 0.084 \\
(8)\end{array}$ & $\begin{array}{c}0.908 \pm 0.167 \\
(10)\end{array}$ \\
\hline Proximal segment & $\begin{array}{c}0.959 \pm 0.082 \\
(10)\end{array}$ & $\begin{array}{c}0.211 \pm 0.171 \\
(20)_{\mathrm{p}}\end{array}$ & $\begin{array}{c}0.134 \pm 0.036 \\
(10)_{p}\end{array}$ & $\begin{array}{c}1.215 \pm 0.358 \\
(13)\end{array}$ \\
\hline Distal segment & $0.483 \pm 0.091$ & $\begin{array}{c}0.311 \pm 0.176 \\
(18)_{p}\end{array}$ & $\begin{array}{c}0.146 \pm 0.071 \\
(14) p\end{array}$ & $\begin{array}{c}0.575 \pm 0.100 \\
(10)\end{array}$ \\
\hline
\end{tabular}

${ }^{1}$ Expressed as log ( $\mu \mathrm{gm}$ alpha-naphthol liberated/ $\mu \mathrm{gm}$ total Kjeldahl nitrogen +1 ) followed by standard deviation.

Total number of animals used appear in brackets. Subscript " $p$ " denotes each sample analysed is derived from two animals, so that the effective $N=1 / 2$ number within brackets.

epididymis than in the distal portion $(\mathrm{P}<0.01)$. Castration for 30 or 60 days results in significant decreases $(P<0.01)$ in specific activity of the whole epididymis. Whole epididymis 60 days after castration shows significantly lower specific activity $(\mathrm{P}<0.01)$ than does whole epididymis 30 days after castration. Specific activity in proximal portions of epididymis is significantly greater $(P<0.01)$ in intact animals than in animals castrate for 30 or 60 days. Proximal segments from animals castrate 30 or 60 days show equivalent specific activities $(P=0.4)$. Distal segments show significant decreases in specific activity following castration for 30 days 
$(\mathrm{P}<0.05)$ or 60 days $(\mathrm{P}<0.01)$. Animals castrate 60 days show lower alkaline phosphatase activity in distal segments than those castrate for 30 days $(P<0.05)$. Castration for 30 or 60 days abolishes the difference in enzyme activity between proximal and distal segments $(P=0.1)$.

Subcutaneous administration of $10 \mu \mathrm{gm}$ testosterone propionate (Schering) in $0.1 \mathrm{ml}$ sesame oil daily for 14 days to animals castrate for 30 days restores alkaline phosphatase activity to normal or above normal levels. Specific activity of whole epididymis from normal animals is comparable to that from castrates maintained by testosterone propionate $(P=0.8)$. Distal segments from normal animals and hormone treated castrates show equivalent alkaline phosphatase activity $(\mathrm{P}=0.2)$ but proximal segments from hormone treated castrates show significant elevation of specific activity over normal $(\mathrm{P}<0.05)$.

\section{Aliesterase in the normal and castrate animal}

In all regions of the head basal cells show moderate levels of aliesterase activity in the cytoplasm. The connective tissue stroma, the muscularis, and the capillaries in all regions show no detectable enzyme activity. The nuclei of all cells are negative. Heat inactivated control sections show no dye formation.

Lobe 1 shows high aliesterase activity throughout the cytoplasm of all epithelial cells (fig. 7). The epithelinm of Lobe 2 shows low levels of enzyme activity (fig. 7 ). Occasional cells in this region show slightly elevated levels of pigment deposition. Ciliated cells in Lobe 3 show levels of aliesterase activity comparable to those prevailing in Lobe 2 (fig. 8 ). The non-ciliated cells of Lobe 3 show intense enzymatic activity (fig. 8). In these cells the enzyme appears to be concentrated in a cap-like region at the cell apex, the remainder of the cytoplasm shows moderate activity (fig. 9). Sections incubated for the dual localization of alkaline phosphatase and aliesterase show these cells to be identical with the 
alkaline phosphatase negative cells of this lobe (fig. 9). Lobes 4, 5 and 6 show progressively increasing aliesterase activity (fig. 10). Considerable variation in intensity of pigment deposition from cell to cell is evident in these regions. The epithelium of Lobe 7 exhibits abrupt depression of aliesterase activity to levels prevailing in Lobe 2 (fig. 11). Dye is evenly distributed in the cytoplasm of ciliated cells save for a less dense area mid-way between the nucleus and cell apex in a region probably occupied by the Golgi body (Benoit, '26).

The junction of head and body segments of the epididymal canal is characterized by abrupt development of very intense aliesterase activity in isolated cell groups (fig. 12). The epithelium of the body and tail segments also shows intense enzymatic activity in the majority of its cells (figs. 13 and 14). Isolated cells, however, show very low aliesterase activity (fig. 13). The activity of basal cells in the body and tail is not known. Dense dye deposition in these regions after 5 minutes incubation obscures basal cell activity. Shorter periods of incubation are not sufficient to demonstrate basal cell activity in any region of the epididymis.

Study of longitudinal and sub-serial transverse sections shows the above described differences in aliesterase activity to be lobe specific and the changes from lobe to lobe to be abrupt.

Castration for 30 or 60 days reduces aliesterase activity in the more active segments of the epididymal canal (Lobe 1, Lobe 3 et seq.) (figs. 15 and 16) but enzymatic pigment production in ciliated cells of Lobes 2, 3 and 7 remains unchanged. Aliesterase activity in basal cells is abolished. Enzyme activity in epithelial cells of Lobes 4, 5 and 6 and the non-ciliated cells of Lobe 3 is comparable to that seen in Lobes 2 and 7 and in the ciliated cells of Lobe 3 of non-castrate animals.

Subcutaneous administration of $10 \mu \mathrm{gm}$ testosterone propionate (Schering) in $0.1 \mathrm{ml}$ sesame oil for 14 days to animals 
castrate for 30 days restores the pattern of aliesterase activity to that seen in normal control animals.

Quantitative determinations of aliesterase specific activity support the above histochemical observations (table 2). Proximal segments of epididymis from intact animals show significantly less aliesterase activity than distal segments $(P<0.01)$. No significant difference exists between animals orchidectomized 30 or 60 days $(P>0.05)$; therefore, these

TABLE 2

Specific activity ${ }^{1}$ of aliesterase in mouse epididymis

\begin{tabular}{|c|c|c|c|}
\hline & INTACT & $\begin{array}{c}\text { CASTRATE } 30 \\
\text { AND } 60 \text { DAYS }\end{array}$ & $\begin{array}{c}\text { CASTRATI } 30 \text { DAYS } \\
\text { PLUS } 10 \mu \mathrm{GM} \\
\text { TESTOSTIRONR } \\
\text { PROPIONATE } \\
\text { DAILY FOE 14 DAYS }\end{array}$ \\
\hline Whole epididymis & $\begin{array}{c}1.130 \pm 0.160 \\
(9)\end{array}$ & $\begin{array}{c}0.805 \pm 0.211 \\
(31)\end{array}$ & $\begin{array}{c}0.972 \pm 0.210 \\
(11)\end{array}$ \\
\hline Proximal segment & $\begin{array}{c}0.867 \pm 0.135 \\
(10)\end{array}$ & $\begin{array}{c}0.715 \pm 0.214 \\
(\mathbf{3 0}) \mathrm{p}\end{array}$ & $\begin{array}{c}1.036 \pm 0.359 \\
(13)\end{array}$ \\
\hline Distal segment & $\begin{array}{c}1.476 \pm 0.200 \\
(8)\end{array}$ & $\begin{array}{c}0.768 \pm 0.217 \\
(30)\end{array}$ & $\begin{array}{c}1.253 \pm 0.299 \\
(13)\end{array}$ \\
\hline
\end{tabular}

${ }^{1}$ Expressed as log ( $\mu$ gm alpha-naphthol liberated/ $\mu$ gm total Kjeldahl nitrogen) followed by standard deviation.

Total numbers of animals used appear in brackets. Subscript " $p$ " denotes each sample analysed is derived from two animals, so that the effective $N=1 / 2$ number in bracket.

groups have been pooled. Castration results in a significant lowering of the specific activity of whole and distal segments of epididymis $(\mathrm{P}<0.01)$. Aliesterase activity of proximal segments shows only questionable lowering following orchidectomy $(P=0.1-0.05)$. Proximal and distal segments show comparable activity in the castrate animal $(P=0.1)$. Subcutaneous administration of $10 \mu \mathrm{gm}$ testosterone propionate (Schering) daily for a period of 14 days to animals castrate for 30 days restores aliesterase activity of whole, proximal and distal segments to normal levels $(P=0.2)$. 
DISCUSSION

The results reported above demonstrate a degree of physiological complexity in the epididymal canal which could not have been predicted from classical morphological study. In the head seven regions may be distinguished on the basis of activity and distribution of alkaline phosphatase and aliesterase. These regions are lobe specific and the differentiation between segments of the epididymal canal is precipitous. The presence of non-ciliated cells in the third lobe of the head represents a further morphological and biochemical differentiation. The body and the tail appear, on the basis of activity and distribution of alkaline phosphatase and aliesterase, to be physiologically similar.

Alkaline phosphatase activity in connective tissues and epithelial cells of the epididymis is clearly under the control of androgenic hormone. Hormonal influences upon connective tissue enzyme activity have been noted previously by Bern ('49) in the sex accessory glands of several species and by Allen and Slater ('56) in the adrenal cortex and medulla of the mouse. The presence of moderate alkaline phosphatase activity in the longitudinal muscle fibers of the tail in contrast to low activity in the circular fibers is intriguing. A similar observation has been made by Atkinson and Elftman ('47) in the myometrium of mouse uterus. Bern ('49) has noted the restriction of epithelial alkaline phosphatase activity to the head of the mouse epididymis where the enzyme is under the control of male hormone. Wislocki ('49) makes no mention of regional differences in alkaline phosphatase activity in the epididymis of the Virginia deer but indicates that the enzyme responds to seasonal variation in testis activity. Maneely ('55) found no regional differences to be present in the epithelium of rat epididymis.

Epithelial aliesterase activity in the epididymal canal is also under androgenic control. Both chemical and histochemical observations indicate that the enzyme in the ciliated cells of Lobes 2, 3 and 7 is not affected by castration but marked loss of activity follows this treatment in all other 
regions of the epididymis. The failure of quantitative determinations to show significant lowering of aliesterase activity in proximal segments following orchidectomy is due, no doubt, to the dilution of total enzyme activity by these low activity regions. Castrate levels of activity in the affected regions are comparable to the activity prevailing in Lobes 2,3 and 7 both before and after orchidectomy. These observations suggest that a component of esterase activity in this tissue is independent of androgenic control.

Definite physiological roles cannot be assigned to alkaline phosphatase and aliesterase. Rosenberg and Wilbrandt ('52) have postulated a mechanism of transmembrane transport of hexose involving alkaline phosphatase. The localization of alkaline phosphatase reported in this paper is consistent with such a suggestion. The ability of spermatozoa to utilize fructose and glucose as metabolic substrates (Lardy, '52) suggests a secretion of carbohydrate into the lumen of the epididymal canal. No physiological action for aliesterase has been suggested. The biochemical properties of this enzyme ( $\mathrm{s}$ ) indicate activity in some phase of lipid metabolism (Ammon and Jaarma, '50).

As to the intervention of the epididymal cells and/or their secretion in the functional differentiation of spermatozoa, no conclusions can be drawn from the present study. The complex organization of the epididymal canal reported here no doubt denotes an equally complex physiological function in the maintenance and perhaps the differentiation of spermatozoa. Clearly further studies are needed before a meaningful account of epididymal function can be given.

\section{SUMMARY}

The distribution and specific activity of alkaline phosphatase and aliesterase in the epididymis of normal and castrate mice has been investigated:

1. Alkaline phosphatase in epithelial cells is confined to the head segment of the epididymal canal. Lobes 1 and 2 of the epididymal canal show no activity. Subsequent segments 
of the head show progressively increased activity. Nonciliated cells in Lobe 3 show no alkaline phosphatase activity. Castration abolishes enzyme activity in epithelial cells.

2. Alkaline phosphatase is present in capillaries and connective tissues of all regions of the epididymis. Longitudinal muscle fibers in the tail contain moderate amounts of alkaline phosphatase. Castration lowers enzyme activity in all these structures save capillaries.

3. Aliesterase is present only in epithelial cells of the epididymal canal. Lobe 1 shows moderate activity. Cells of Lobe 2 and ciliated cells of Lobe 3 show low levels of activity. Non-ciliated cells of Lobe 3 show intense activity. Activity increases progressively in Lobes 4,5 and 6 but drops to low levels in Lobe 7. Basal cells in the head are moderately active. Intense activity is present in the body and tail of the epididymis.

4. Castration does not affect aliesterase activity in the ciliated cells of Lobes 2, 3 and 7; activity in all other cells is depressed.

5. Testosterone propionate reverses the effects of castration.

\section{LITERATURE CITED}

Allen, J., AND J. SLATER 1956 Influence of hormones upon the distribution of alkaline phosphatase in mouse adrenal cortex. J. Histochem. Cytochem., 4: 110-117.

AMMON, R., AND M. JAARMA 1950 Enzymes hydrolyzing fats and esters. In the Enzymes I, J. Sumner and K. Myrbäck, editors. Academic Press, Ine., New York. Chap. IX, 390-442.

Atrinson, W., and H. ElfTMan 1947 Mobilization of alkaline phosphatase in the uterus of the mouse by estrogen. Endocrinology, 40:30-36.

Benoit, J. 1926 Recherches anatomiques, eytologiques et histophysiologiques sur les voies excrétrices du testicule, chez les mammifères. Arch. anat., hist. et embr., $5:$ 175-412.

BerN, H. 1949 The distribution of alkaline phosphatase in the genital tract of male mammals. Anat. Ree., 104: 361-377.

Chessick, R. 1953 Histochemical study of the distribution of esterases. $J$. Histochem. Cytochem., 1: 471-485.

Fishman, W., AND J. BAKER 1956 Cellular localization of beta-glucuronidase in rat tissues. J. Histochem. Cytochem., 4: 570-587.

Gomori, G. 1953 Human esterases. .5. Iab. Clin. Med., 42: 445-453. 
Hawk, P. 1951 Practical Physiological Chemistry. The Blakiston Co., Philadelphia. Chap. XXXII, 820-822.

IWAHASHI, S. 1952 Distribution of acid and alkaline phosphatase in the kidney and epididymis of the intact and castrated lizards. Dobutugaku zassi, 61: 265-268.

LARDY, H. 1952 The metabolic regulator in mammalian spermatozoa. In Studies on Testis and Ovary Eggs and Sperm, E. Engle, editor. Charles C. Thomas, Springfield, Illinois. Chap. VI, 111-122.

MANeELY, R. 1955 The distribution of polysaccharide complexes and of alkaline phosphatase in the epididymis of the rat. Acta. Anat., 4: 314-329.

Mason, K., AND S. SHAVER 1952 Some functions of the caput epididymis. Ann. N. Y. Acad. Sei., 55: 585-593.

Montagna, W. 1952 Some eytochemical observations on human testes and epididymides. Ann. N. Y. Acad. Sci., 55: 629-642.

NICANDER, L. 1954 Glyeogen secretion in the epididymis. Nature (London), 174: 700-701.

Pearse, E. 1953 Histochemistry, Theoretical and Applied. Little, Brown and Company, Boston. App., 402-490.

Rosenberg, T., aND W. WilbrandT 1952 Enzymatic processes in cell membrane penetration. In International Review of Cytology I, G. Bourne and J. Danielli, editors. Academic Press, Inc., New York. 65-92.

WislockI, G. 1949 Seasonal changes in the testes, epididymides and seminal vesicles of deer investigated by histochemical methods. Endocrinology, 44: $167-189$.

Yoong, W. 1931 A study of the function of the epididymis III. Funetional changes undergone by spermatozoa during their passage through the epididymis and vas deferens in the guinea-pig. J. Exp. Biol., 8: 151-162. 
PLATES 


\section{PLATE 1}

EXPIAANATION OF FIGURES

1 Distribution of alkaline phosphatase in terminal segment of efferent luct (top) and initial segment of epididymal canal (bottom). Epithelial cells are negative but stromal connective tissues and capillary endothelium show moderate enzyme activity. 10 minutes incubation, $20^{\circ} \mathrm{C}, \times 60$.

2 Distribution of alkaline phosphatase in Lobe 3 of epidiclymal canal. Strong enzyme activity is present in eilia and apical regions of epithelint eells. Stromal connective tissues show moderate actjity. Non-ciliated cells are negative for alkaline phosphatase; the clearly visible negative areas (eircular spots) seen in the dense portions of the photograph are due to the non-reactive apical regions of these cells. 10 minutes incubation, $20^{\circ} \mathrm{C}$, $\times 60$.

3 Distribution of alkaline phosphatase in Lobe 4 (top) and Lobe 5 (bottom) of the epididymal canal. Same distribution of enzyme as seen in eiliated cells of figure 2 but increased activity in epithelium is noted. 10 minutes incubation, $20^{\circ} \mathrm{C} ., \times 60$.

4 Distribution of alkaline phosphates in Lobe 6 (top) and Lobe 7 (bottom) of epididymal canal. Enzyme activity of epithelium is diminished in intensity in Lobe 6 and is absent in Iobe 7. Stromal connective tissues show alkaline phosphatase activity comparable to that seen proviously. 10 ninutes incubation, $20^{\circ} \mathrm{C} ., \times 60$.

5 Distribution of alkaline phosphatase in distal portion of tail. Epithelium of epididymal canal shows no enzyme activity but lamina propria and longitudinal muscle fibers show moderate activity, circular muscle fibers are negative for alkaline phosphatase. 10 minutes incubation, $20^{\circ} \mathrm{C}$., $\times 60$.

6 Distribution of alkalime phosphatase in Lobe 5 of epididymal canal. Animal castrate 30 days, no further treatment. Enzyme activity is abolished except for eapillary endothelium which is unaffected. 10 minutes incubation, $20^{\circ} \mathrm{C}$., $\times 60$. 
J. M. ALLEN AND J. J. SLATER
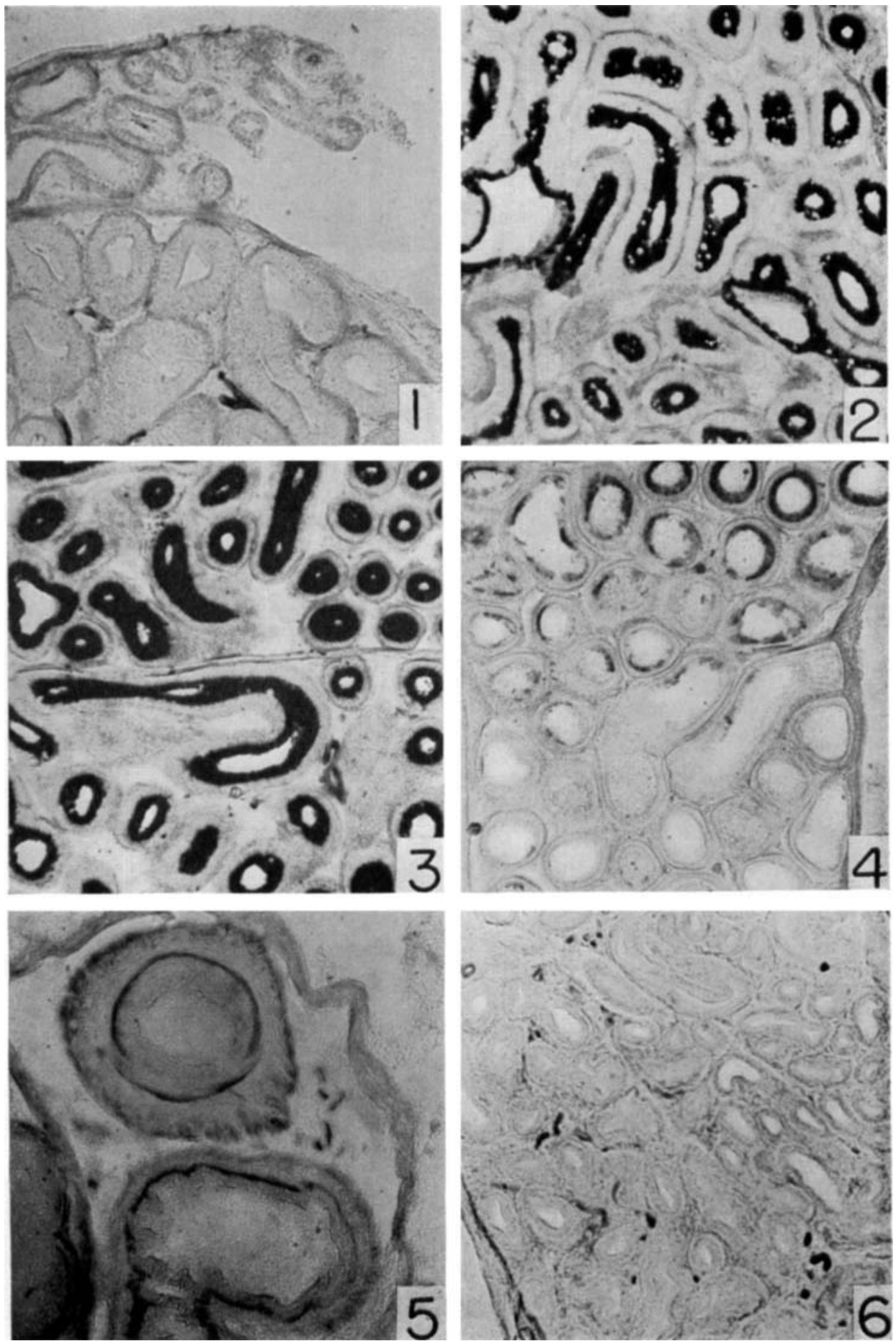


\section{PLATE 2}

EXPLANATION OF FIGURES

7 Distribution of aliesterase in terminal segment of efferent duct (top) and initial segment of epididymal eanal (bottom). Efferent duct shows high activity but initial segment of eanal shows only low aliesterase activity. Basal cells show moderate levels of activity. Connective tissue stroma is negative. 5 minutes incubation, $20^{\circ} \mathrm{C}$., $\times 60$.

8 Aliesterase activity in Lobe 3 of epididymal canal. Ciliated cells of epithelium show levels of enzyme activity comparable to those seen in figure 7 (initial segment) but club-shaped non-ciliated cells show intense aliesterase activity. Basal cells show moderate aetivity. Commective tissue stroma is negative. 5 minutes incubation, $20^{\circ} \mathrm{C}$., $\times 60$.

9 Dual localization of alkaline phosphatase and aliesterase in Lobe 3 of epididymal canal. Alkaline phosphatase is concentrated in the cilia (obseured by dye particles) and apical margins of most cells. Aliesterase is present in high titer in club-shaped non-ciliated cells. Concentration of aliesterase in apical region of non-ciliated cells is visible, remainder of cytoplasm shows moderate levels of activity, the nucleus is negative. Basal cells show moderate activity. 10 minutes incubation (alkaline phosphatase), 5 minutes incubation (aliesterase), $20^{\circ} \mathrm{C} ., \times 180$.

10 Distribution of aliesterase in Lobe 5 (top) and Lobe 6 (bottom) of epididymal canal. Inerease in activity of the enzyme is evident ( $c f$. figs. 7 and 8 ). Marked variation in aliesterase activity from cell to cell is particularly evident in Lobe 6. 5 minutes ineubation, $20^{\circ} \mathrm{C}$., $\times 60$.

11 Aliesterase distribution in Lobe 6 (top) and Lobe 7 (bottom) of epididymal canal. Abrupt depression of enzyme activity is noted in Lobe 7. Compare aliesterase activity in Iobe 7 with that in Lobe 2 or 3 (figs. 7 and 8). Basal cell activity is clearly scen. 5 minutes incubation, $20^{\circ} \mathrm{C}$, $\times 60$.

12 Aliesterase activity in transitional zone between Lobe 7 and the body segment of epididymal canal. Note the development of intense aliesterase activity in isolated cells of otherwise low activity epithelium. Basal cells, when visible, show moderate activity. 5 minutes incubation, $20^{\circ} \mathrm{C}$, $\times 60$. 
J. M. ALLEN AND J. J. SLATER
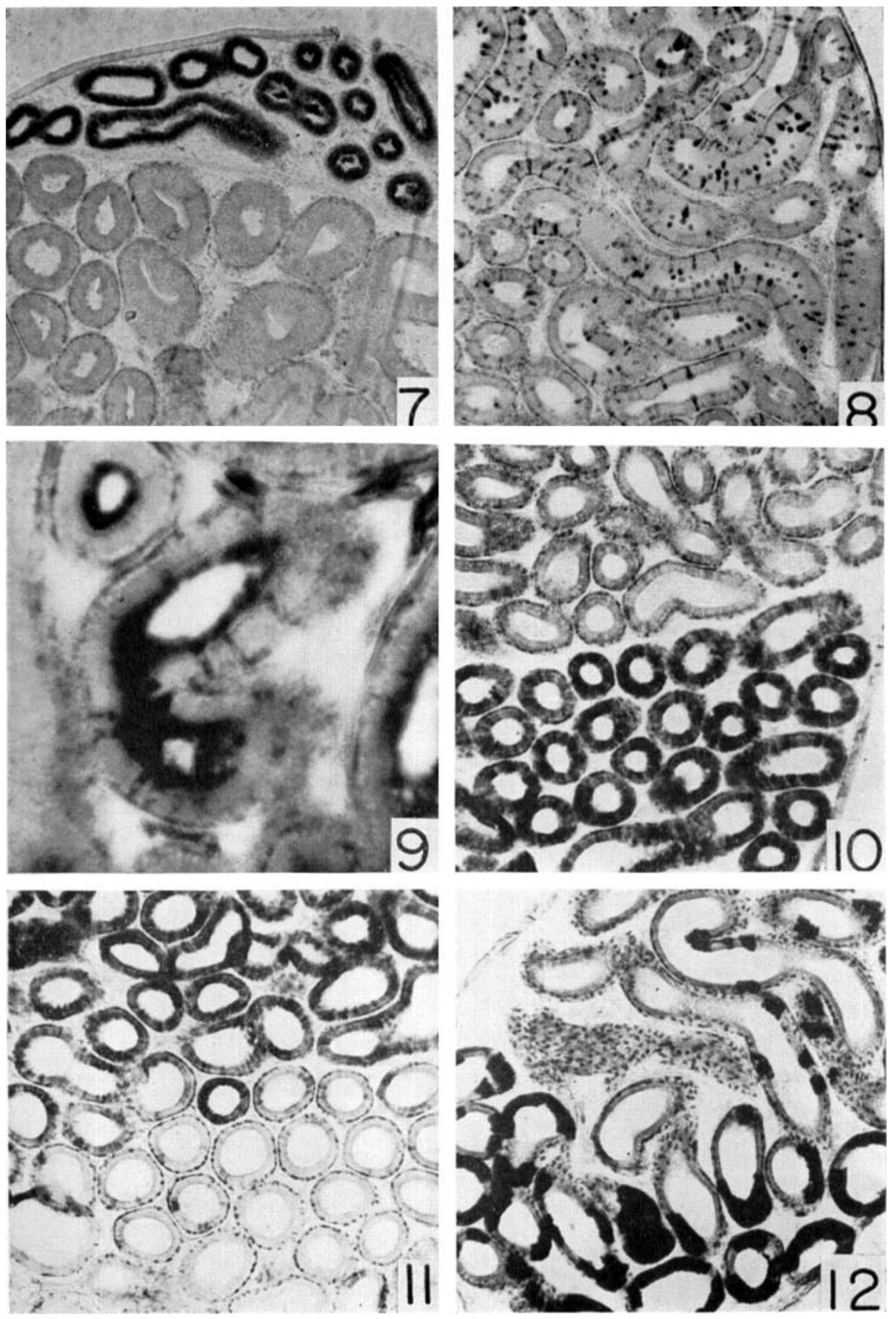


\section{PLATE 3}

EXPLANATION OF FIGURES

13 Aliesterase localization in body of epididymis. Most cells in epithelium show intense activity but isolated cells show very low activity (arrow). Basal ecll activity is not evident. 2 minutes incubation, $20^{\circ} \mathrm{C}$, $\times 60$.

14 Aliesterase activity in proximal (top) and distal (bottom) segments of tail portion of epididymal canal. Intense enzyme activity obseures cell detail. 5 minutes incubation, $20^{\circ} \mathrm{C}$., $\times 60$.

15 Aliesterase activity in Tobe 5 (top) and Lobe 6 (bottom) of epididymal camal in animal castrate 30 days. Compare prevailing levels of activity with those in figures 7,8 and 10. 5 minutes incubation, $20^{\circ} \mathrm{C}$, $\times 60$.

16 Aliesterase activity in proximal (top) and distal (bottom) segments of tail portion of epididymal canal in animal castrate 30 days. Compare prevailing levels of activity with those seen in figures 7,8 and 14. 5 minutes ineubation, $20^{\circ} \mathrm{C} ., \times 60$. 

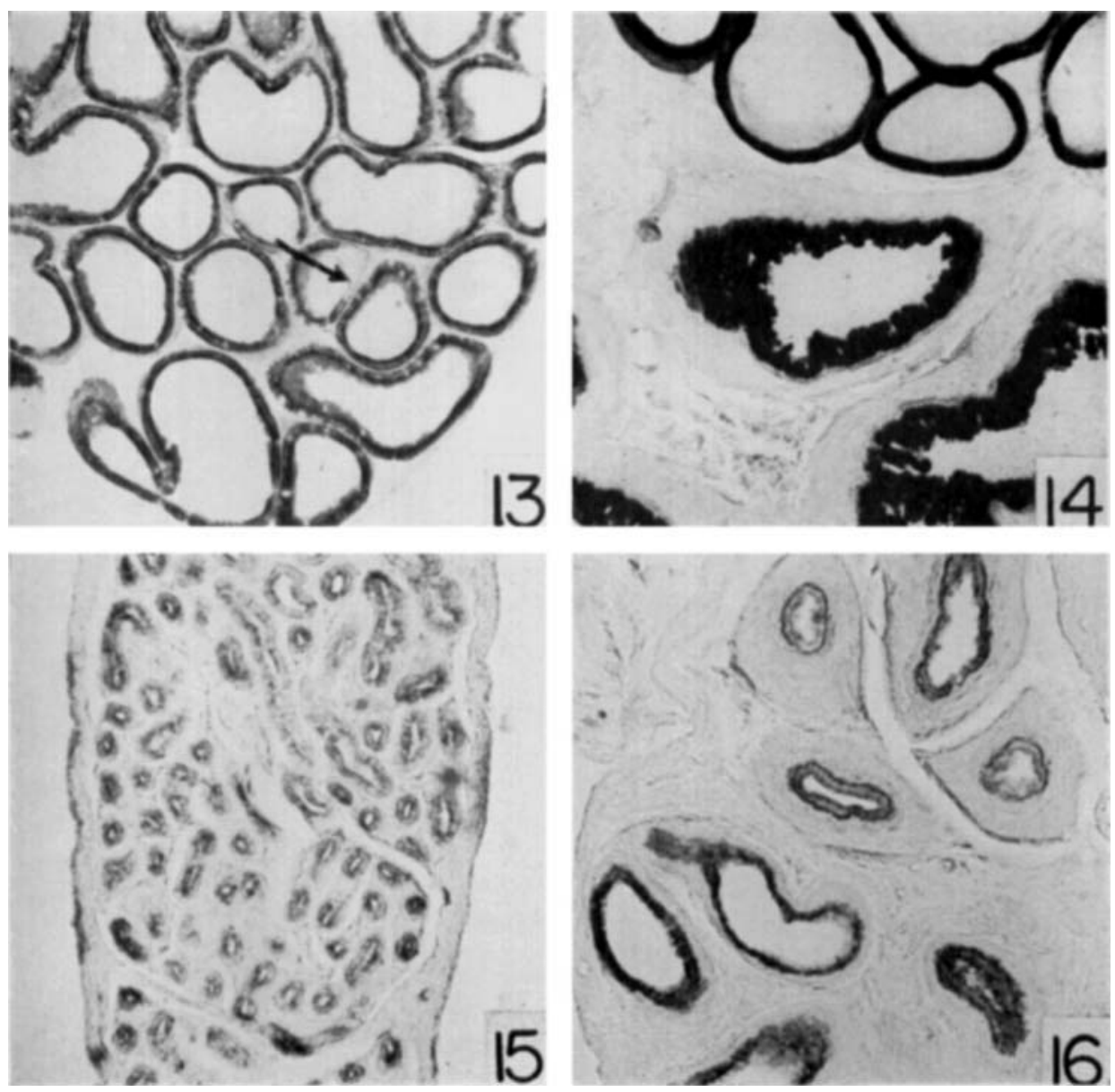